\title{
Bacteriological and Physicochemical Assessment of Drinking Water Collected from the Private Selling Sites of Urban Areas of Khamis Mushait City-KSA
}

\author{
Ibrahim E. Abdelrahman ${ }^{1}$, Alaa M. Khozimy ${ }^{2 *}$, Ali M. Alshehri ${ }^{3}$ and Naif A. Alshehri ${ }^{4}$ \\ ${ }^{1,3,4}$ Khamis Mushait Municipality, Aseer Region, KSA \\ ${ }^{2}$ Plant Protection Department, Faculty of Agriculture, Damanhour University, Egypt
}

Received: 10/9/2019

\begin{abstract}
This study was conducted in the urban area of Khamis Mushait City, Aseer Region, and Saudi Arabia. A total of 50 samples of drinking water were collected from private selling sites of unbolted water in the urban area of Khamis Mushait city. Physicochemical parameters such as $\mathrm{pH}$, total dissolved solids (TDS), and electrical conductivity (EC) of water samples were measured using standard methods to assess the quality of drinking water. The $\mathrm{pH}$ values of water samples ranged from $6.56 \pm 0.1$ to $8.5 \pm 0.49$, TSD changed from $104.7 \pm 0.28$ to $202.4 \pm 1.7 \mathrm{mg} /$ liter and EC from $163.6 \pm 0.45$ to $316.3 \pm 2.61 \mu \mathrm{S} / \mathrm{cm}$. The previous results indicated that all physicochemical parameters are within the permissible limits of WHO (2011) for drinking water quality. The bacteriological examination of water samples included the most probable number (MPN/100 ml) of coliforms, E.coli and Pseudomonas aeruginosa. The results showed that $E$. coli bacterium was not detected in all samples, while total coliform group was found in 7 samples out of 50 samples analyzed (14\%) and Pseudomonas aeruginosa was found in 24 samples out of a total of 50 samples (48\%). Furthermore, this study has revealed that about $54 \%$ of the water samples collected from private selling sites is incompatible to the World Health Organization (WHO) standards for drinking water quality.
\end{abstract}

Keywords: Khamis Mushait City, Aseer Region, coliforms, E. coli, Pseudomonas aeruginosa, (TDS), pH

\section{INTRODUCTION}

Clean-safe drinking water is required for the sustenance of life and it is a fundamental human need. Drinking water must be safe to drink or to use for food preparation. Water is essential to life; each person on earth requires at least 20 to 50 liters of clean safe water a day for drinking, cooking, and cleaning. But, normal healthy person needs to drink about 8 glasses (2 liters) of water per day, depending upon several factors, including gender, age, level of activity and environment. World Health Organization (WHO, 1996), has developed guidelines for drinking water quality, provides the basis for the development of national standards that, if properly implemented, will ensure the safety and quality of drinking water, as well as preparation of international standards on water quality and human health in a form of guidelines of regulations and standards that serve as the basis for organization and standard setting around the world.

Saudi Arabia is the world's largest producer of desalinated water which covers $70 \%$ of the total water demand (Ahmad and Bajahlan, 2009). The private selling sites in the urban areas of Khamis Mushait city provide the drinking water by tankers from the main source of government water desalination and sold it in a small twenty-liter reusable container to the consumers. Contaminate water, poor hygiene, and bad sanitation cause over $80 \%$ of diseases in developing countries (WHO, 1998). Many researchers such as Zacheus et al. (2001), Leguori (2010) and Rifaat et al. (2007) reported bacterial contamination of drinking water in developing and some developed countries. Detection of $E$. coli or enterococci is recommended for monitoring fresh water, whereas enterococci are the preferred indicator bacteria for marine waters because of their salt tolerance (USEPA, 2004).

In a previous study about the bacteriological assessment of urban water sources in Khamis Mushait
City, Fecal coliform was detected in desalinated, surface water and well water with percentages of 3.23 , 60.0 , and 87.88, respectively (AlOtaibi E. L. Sh., 2009).

In general, organisms which are potential diseaseproducers are five types, bacteria, protozoa, worms, viruses, and fungi. The presence of certain organisms of these various types can lead to such infectious diseases as typhoid fever, dysentery, cholera, jaundice, hepatitis, guardians, undulant fever, and tularemia, as well as other diseases which spread through unfit drinking water. In addition to the presence of contaminants, other factors assessed when determining portability include taste, odor, and turbidity, or cloudiness. Some of these issues can be resolved as the water goes through processes such as settling, filtering, and disinfecting. Drinking water should be clear, not saline and free from compounds that can change color, taste, and odor. Presence of Coliform bacteria in drinking water indicates that disease-causing organisms (pathogens) could be in the water system. Most pathogens that can contaminate water supply come from the feces of humans or animals.

Pseudomonas aeruginosa is a common bacterium, Gram-negative opportunistic pathogen capable of infecting humans with compromised natural defenses and causing severe pulmonary diseases, occurs widely in the environment such water, soil, sewage, animal feces, and on vegetation, also occurs to many foodstuffs and may often be present in the digestive tract of humans without causing any signs of illness. Pseudomonas aeruginosa is a waterborne opportunistic pathogen which may have impacts on human health, especially in immune-compromised populations (Wang et al., 2012).

$\mathrm{pH}$ value is an important factor in maintaining carbonate and bicarbonate levels in water whereas, total dissolved solids (TDS) is used to describe the 
inorganic salts and small amounts of organic material present in water (WHO, 1996).

The Main purposes of the present study are to investigate the bacteriological and physicochemical quality of drinking water sold in the urban area of Khamis Mushait City, which provide us good information about the safety of this water. Furthermore, the study expected to provide important and valuable information to Khamis Mushait Municipality about the extent of pollution that facing the private selling sites of drinking water. In addition, can also help devise long-term strategies to improve water quality.

\section{MATERIALS AND METHODS}

\section{Location of Study area:}

Khamis Mushait is one of an important city found in Aseer Region, Saudi Arabia. It is located 18.30 latitude and 42.73 longitudes and it is situated at elevation 1998 meters above sea level. Khamis Mushait has a population of 387,553 making it the biggest city in Aseer region.

Water samples were collected from an urban area of Khamis Mushait city. The urban area was divided into five geographic regions (Central, Eastern, Western, Southern, and Northern regions) in terms of the distribution of private water selling points (Figure1).

\section{Collection of water samples:}

The study was conducted from September to October 2018. The Samples of the drinking water were collected from the urban area of Khamis Mushait city covering, Northern region (9 samples), Western region (7 samples), Southern region (11 samples), Eastern region (13 samples) and Central Region (10 samples) Table (1)

Table (1): The number of drinking water samples taken from sites in each region

\begin{tabular}{lc}
\hline Geographic Region & $\begin{array}{c}\text { Number of drinking } \\
\text { water sites }\end{array}$ \\
\hline Northern Region & 9 \\
Southern Region & 11 \\
Western Region & 7 \\
Northern Region & 9 \\
Eastern Region & 13 \\
\hline Total samples & 50 \\
\hline
\end{tabular}

A total of 50 drinking water samples were collected and analyzed for bacteriological (Total coliform, E. coli, and Pseudomonas aeruginosa) and physicochemical parameters ( $\mathrm{pH}$, TDS, EC), following standard procedures to avoid any contamination. The samples were collected in clean sterile glass bottles with screw caps under aseptic conditions (Bottles for bacteriological analysis contain sodium thiosulfate to neutralize any residual disinfectant). After collection, the water samples immediately kept on the ice-box, and transported to the Food Safety and Environment laboratory of Khamis Mushait Municipality, Saudi Arabia, and preserved at $4^{\circ} \mathrm{C}$ until analysis within 3 to 6 hours.

\section{Bacteriological Analysis:}

\section{Enumeration of Total Coliforms and $E$. coli:}

The most probable number (MPN) technique was followed as described in the Standard Methods for the Examination of Water and Wastewater (APHA, 2000) by using the Colilert 18 medium (IDEXX Laboratories, Westbrook, ME, USA-2015) with appropriate dilutions. $100 \mathrm{ml}$ of water sample was mixed with one snap of colilert 18, the mixture poured into the Colilert tray - Quanti-Tray/2000, and sealed within an IDEXX Quanti-Tray Sealer. The sealed Quanti-tray was incubated at $35^{\circ} \mathrm{C} \pm 0.5$ for $18-24$ hours. A yellow color after incubation was considered as a positive total coliform while the wells with yellow color gave fluorescence under UV illumination (366 nm) was considered as $E$. coli positive. The number of positive wells in each Quanti-Tray/2000 was counted and the corresponding most probable (MPN) was obtained from the MPN table provided with the Quanti Tray/2000. Results of each sample were calculated and reported as MPN/100ml (IDEXX Laboratories, 2013).

\section{Enumeration of Pseudomonas aeruginosa:}

One hundred milliliters of water sample was added to a sterile $120 \mathrm{~mL}$ vessel containing an antifoam reagent (ISO 16266-2:2018). One snaps pack of Pseudalert ${ }^{\circledR}$ reagent was added, the vessel capped and the sample was shaken to dissolve the reagent before being left to stand for any foam to settle. The sample was then poured into a Quanti-Tray/2000 (IDEXX Laboratories, USA-2013), sealed and incubated at $38 \pm 0.5^{\circ} \mathrm{C}$ for $24-28$ hours. After incubation, the Quanti-Trays ${ }^{\circledR}$ were examined under UV irradiance $(365 \mathrm{~nm})$, and all wells demonstrating blue fluorescence compared to a negative blank sample were counted as positive for Pseudomonas aeruginosa. Results were reported as MPN/100ml using the table provided with Quanti-Tray/2000, (IDEXX Laboratories, USA-2013).

\section{Physicochemical Analysis:}

Physicochemical parameters such as $\mathrm{pH}$, total dissolved (TDS), and electrical conductivity (EC) of the drinking water samples were measured using standard methods as described in the APHA (1998).

\section{Determination of pH:}

The $\mathrm{pH}$ values of the water samples was determined by using a digital $\mathrm{pH}$ meter $\mathrm{AB} 15 \mathrm{j}$ Fisher Scientific, $100 \mathrm{ml}$ of each sample was poured into a sterile beaker and the electrode of the $\mathrm{pH}$ meter was dipped into it and readings were obtained when it was stable. 


\section{Determination of TDS and EC:}

The Electrical Conductivity (EC) was determined in the laboratory by a conductivity meter (SesIon 7 , Hach Company, USA). The electrode was dipped into $100 \mathrm{ml}$ of the water sample, and the reading was recorded when it was stable. The TDS can be calculated by multiplying the EC by a predetermined factor. The factor determined gravimetrically ranges between 0.55 and 0.9 , in this study the factor value used was 0.64 .

\section{Statistical Analysis:}

Each sample was analyzed in triplicate and the figures were then averaged. The statistical analysis was performed with SAS program (SAS.1990) using of variance (ANOVA) and means were separated by Duncan's multiple range tests with a probability $\mathrm{P} \leq$ 0.05 (Steel and Torrie, 1980).

\section{RESULTS AND DISCUSSION}

Physicochemical parameters:

The results of the physicochemical parameters of drinking water (50 samples) collected from all regions were summarized in Table (2) (a, b, c, d, and e).

The results of 10 samples collected from the central region showed that the $\mathrm{pH}$ values ranged from 7.09 to 7.82 with an average of 7.42, TDS from 133.6 to $154.9 \mathrm{mg} / \mathrm{liter}$ with an average of 148.8 , and EC values varied from 208.7 to $242.0 \mu \mathrm{S} / \mathrm{cm}$ with an average 232.5 (Table 2a). The results of 11 samples from the southern region; revealed that $\mathrm{pH}$, TDS, and EC were ranged from 7.22 to 8.20 with an average value 7.59 , from 149.2 to 161.9 with an average value $155 \mathrm{mg} / \mathrm{l}$, from 233.1 to 252.9 with an average value $242.2 \mu \mathrm{S} / \mathrm{cm}$ respectively, (Table $2 \mathrm{~b}$ ).

Table (2a): Bacteriological and physicochemical parameters of drinking water samples collected from Central Region of City

\begin{tabular}{|c|c|c|c|c|}
\hline \multirow{2}{*}{ Physicochemical parameters } & \multicolumn{3}{|c|}{ Values determine of central region } & \multirow{2}{*}{$\begin{array}{c}\text { Allowed limits } \\
\text { by WHO }\end{array}$} \\
\hline & Minimum & Maximum & Mean & \\
\hline pH & 7.09 & 7.82 & 7.42 & $6.5-8.5$ \\
\hline TDS mg/l & 133.6 & 154.9 & 148.8 & 1000 \\
\hline E.C $\boldsymbol{\mu S} / \mathrm{cm}$ & 208.7 & 242.0 & 232.5 & 1500 \\
\hline \multirow{2}{*}{$\begin{array}{l}\text { Enumeration of } \\
\text { bacteriological analysis }\end{array}$} & \multicolumn{3}{|c|}{ Values determine of central region } & Allowed limits \\
\hline & Minimum & Maximum & Mean & by WHO \\
\hline Coliform MPN/100ml & 0.0 & 3.1 & 0.31 & 0 \\
\hline E.coli $\mathrm{MPN} / 100 \mathrm{ml}$ & 0.0 & 0.0 & 0.0 & 0 \\
\hline $\begin{array}{l}\text { Pseudomonas aeruginosa } \\
\text { MPN } / 100 \mathrm{ml}\end{array}$ & 0.0 & 8.6 & 2.3 & 0 \\
\hline
\end{tabular}

- Total number of samples $=10$ Drinking water

- Each sample was done in duplicate

Table (2b): Bacteriological and physicochemical parameters of drinking water samples collected from Southern Region of City

\begin{tabular}{|c|c|c|c|c|}
\hline \multirow{2}{*}{$\begin{array}{c}\text { Physicochemical parameters } \\
\text { Mean }\end{array}$} & \multicolumn{3}{|c|}{ Values determine of Southern region } & \multirow{2}{*}{$\begin{array}{l}\text { Allowed limits } \\
\text { by WHO }\end{array}$} \\
\hline & Minimum & Maximum & Mean & \\
\hline pH & 7.22 & 8.20 & 7.59 & $6.5-8.5$ \\
\hline TDS mg/l & 149.2 & 161.9 & 155.0 & 1000 \\
\hline E.C $\mu \mathrm{S} / \mathrm{cm}$ & 233.1 & 252.9 & 242.2 & 1500 \\
\hline \multirow{2}{*}{$\begin{array}{l}\text { Enumeration of } \\
\text { bacteriological analysis } \\
\text { Mean }\end{array}$} & \multicolumn{3}{|c|}{ Values determine of Southern region } & \multirow{2}{*}{$\begin{array}{l}\text { Allowed limits } \\
\text { by WHO }\end{array}$} \\
\hline & Minimum & Maximum & Mean & \\
\hline Coliform MPN/100 ml & 0.0 & 0.0 & 0.0 & 0 \\
\hline E.coli MPN/100 ml & 0.0 & 0.0 & 0.0 & 0 \\
\hline $\begin{array}{l}\text { Pseudomonas aeruginosa } \\
\text { MPN } / 100 \mathrm{ml}\end{array}$ & 0.0 & 9.8 & 4.9 & 0 \\
\hline
\end{tabular}

- Total number of samples $=11$ Drinking water site

- Each sample was done in duplicate 
Table (2c): Physicochemical and bacteriological parameters of drinking water samples collected from Western Region of City

\begin{tabular}{|c|c|c|c|c|}
\hline \multirow{2}{*}{ Physicochemical parameters } & \multicolumn{3}{|c|}{ Values determine of Western region } & \multirow{2}{*}{$\begin{array}{l}\text { Allowed limits } \\
\text { by WHO }\end{array}$} \\
\hline & Minimum & Maximum & Mean & \\
\hline pH & 6.56 & 7.65 & 7.36 & $6.5-8.5$ \\
\hline TDS mg/l & 148.4 & 202.4 & 162.2 & 1000 \\
\hline E.C $\mu \mathrm{S} / \mathrm{cm}$ & 231.9 & 316.3 & 253.5 & 1500 \\
\hline \multirow{2}{*}{$\begin{array}{l}\text { Enumeration } \\
\text { bacteriological analysis }\end{array}$} & \multicolumn{3}{|c|}{ Values determine of Western region } & \multirow{2}{*}{$\begin{array}{l}\text { Allowed limits } \\
\text { by WHO }\end{array}$} \\
\hline & Minimum & Maximum & Mean & \\
\hline Coliform MPN/100ml & 0.0 & 17.2 & 3.5 & 0 \\
\hline E.coli $\mathrm{MPN} / 100 \mathrm{ml}$ & 0.0 & 0.0 & 0.0 & 0 \\
\hline $\begin{array}{l}\text { Pseudomonas aeruginosa } \\
\text { MPN/100ml }\end{array}$ & 0.0 & 2149.6 & 392.7 & 0 \\
\hline
\end{tabular}

- Total number of samples $=7$ Drinking water site

- Each sample was done in duplicate

Values of 7 samples from Western region varied from 6.56 to 7.65 with a mean of 7.36 , from 148.4 to 202.4 with a mean of 162.2 and from 231.9 to 316.3 with a mean 253.5 for $\mathrm{pH}$, TDS, and E.C, respectively (Table 2c).for $\mathrm{pH}$, TDS, and EC, respectively (Table $2 \mathrm{c})$. On the other hand Table (2d) Showed that the values of nine samples of the northern region were found to be ranged from 6.56 to 8.50 for $\mathrm{pH}$ with an average 7.41 , from 124.9 to 192.3 with an average 154.9for TDS and from 195.2 to 300.5 with an average 242.0 for EC. Data of samples from Eastern Region recorded in (Table 2e) indicated that $\mathrm{pH}, \mathrm{TDS}, \mathrm{EC}$ values ranged from 6.85 to 8.33 , with an average 7.68 , from 104.7 to 188.2 with an average 141.8 , and from163.6 to 294 .1 with an average 221.5 , respectively.

The $\mathrm{pH}$ of water is controlled by the carbon dioxide-bicarbonate. The increase of carbon dioxide will lower the $\mathrm{pH}$ concentration, whereas the decrease in it will raise it, as well as the lower than 7 are considered acidic and, that with the $\mathrm{pH}$ more than 7 considered basic. Control of $\mathrm{pH}$ is important in drinking water to minimize the corrosion of water mains and pipes and maintain the taste, odor and appearance (WHO, 1996). Environmental Protection Agency (EPA) regulation doesn't include $\mathrm{pH}$ in drinking water quality, because it's considered an aesthetic quality of water. However, the agency recommends that municipal drinking water suppliers keep their water supply at a $\mathrm{pH}$ of 6.5 to 8.5. Total dissolved solids (TDS) are used to describe the inorganic salts and small amounts of organic material present in water. TDS in water is directly related to conductivity and effect on the taste of water.

The present study concluded that the selected physicochemical parameters of the drinking water fifty samples collected from the private selling sites of the urban area of Khamis Mushait City are varied from 6.56 to $8.50,104.70$ to 202.40 , and 163.60 to 316.30 for $\mathrm{pH}$, TDS, and EC, respectively, these values are falling within the range of the WHO (2011) standards guidelines of drinking water. Therefore, all drinking water samples were found to be fit for human consumption.

Table (2d): Bacteriological and physicochemical parameters of drinking water samples collected from Northern Region of City

\begin{tabular}{|c|c|c|c|c|}
\hline \multirow{2}{*}{ Physicochemical parameters } & \multicolumn{3}{|c|}{ Values determine of Northern region } & \multirow{2}{*}{$\begin{array}{l}\text { Allowed limits } \\
\text { by WHO }\end{array}$} \\
\hline & Minimum & Maximum & Mean & \\
\hline pH & 6.56 & 8.50 & 7.41 & $6.5-8.5$ \\
\hline TDS mg/l & 124.9 & 192.3 & 154.9 & 1000 \\
\hline E.C $\boldsymbol{\mu S} / \mathbf{c m}$ & 195.2 & 300.5 & 242.0 & 1500 \\
\hline \multirow{2}{*}{$\begin{array}{l}\text { Enumeration of } \\
\text { bacteriological analysis }\end{array}$} & \multicolumn{3}{|c|}{ Values determine of Northern region } & Allowed limits \\
\hline & Minimum & Maximum & Mean & by WHO \\
\hline Coliform MPN/100 ml & 0.0 & 8.6 & 1.0 & 0 \\
\hline E.coli MPN/100 ml & 0.0 & 0.0 & 0.0 & 0 \\
\hline $\begin{array}{l}\text { Pseudomonas aeruginosa } \\
\text { MPN/100 ml }\end{array}$ & 0 & 343.6 & 76.8 & 0 \\
\hline
\end{tabular}

- $\quad$ Total number of samples $=9$ Drinking water site.

- Each sample was done in duplicate. 
Table (2e): Physicochemical and bacteriological parameters of drinking water samples collected from Eastern Region of City

\begin{tabular}{|c|c|c|c|c|}
\hline \multirow{2}{*}{ Physicochemical parameter } & \multicolumn{3}{|c|}{ Values determine of Eastern region } & \multirow{2}{*}{$\begin{array}{c}\text { Allowed limits by } \\
\text { WHO }\end{array}$} \\
\hline & Minimum & Maximum & Mean & \\
\hline pH & 6.85 & 8.33 & 7.68 & $6.5-8.5$ \\
\hline TDS mg/l & 104.7 & 188.2 & 141.8 & 1000 \\
\hline E.C $\mu \mathrm{S} / \mathrm{cm}$ & 163.6 & 294.1 & 221.5 & 1500 \\
\hline \multirow{2}{*}{ Enumeration of bacteriological analysis } & \multicolumn{3}{|c|}{ Values determine of Eastern region } & Allowed limits by \\
\hline & Minimum & Maximum & Mean & WHO \\
\hline Coliform MPN/100ml & 0.0 & 20.5 & 2.2 & 0 \\
\hline E.coli $\mathrm{MPN} / 100 \mathrm{ml}$ & 0.0 & 0.0 & 0.0 & 0 \\
\hline Pseudomonas aeruginosa MPN/100ml & 0 & 178.6 & 4.3 & 0 \\
\hline
\end{tabular}

Total number of samples $=13$ Drinking water site

Each sample was done in duplicate

\section{Bacteriological analysis:}

The bacteriological results are summarized in tables (2a, 2b, 2c, 2d, 2e) and compare them to WHO (2011), guidelines of drinking water quality.

The results showed that total coliforms were found in drinking water collected from, Central, Western, Northern and Eastern with a value varied from 0.0 to 3.1 with an average 0.31 , from 0.0 to 17.2 with an average 3.5 , from 0.0 to 8.6 with an average 1.0 and from 0.0 to 20.5 with an average 2.2 $\mathrm{MPN} / 100 \mathrm{ml}$, respectively. However, no coliforms found in the southern region. The drinking water should be free of coliform according to WHO (2011) guidelines for drinking water; their presence in treated drinking water may be due to the ineffectiveness of treatment or post contamination after treatment or poor hygiene. Also, its presence in drinking water indicates that disease-causing organisms (pathogens) could be in the water system. The $E$. coli count is not detected in all drinking water samples taken from different geographic regions, therefore no fecal contaminant. The E. coli bacteria are one the coliform group that indicate fecal pollution and it is also strictly of fecal origin.

The total count of Pseudomonas aeruginosa of Central region was varied from 0.0 to 8.6 with mean
2.3, Southern region from 0.0 to 9.8 with mean 4.9 , the Western region from 0.0 to 2149.6 with mean 392.7 , Northern region, from 0.0 to 343.6 with mean 76.8.7, and Eastern region from 0.0 to 178.6 with mean 4.3 MPN/100ml. Majority of Pseudomonas species are not harmful to humans but Pseudomonas aeruginosa can cause infections in immune-suppressed patients.

The contamination percentage of total coliforms was found (14\%), Pseudomonas aeruginosa (48\%), and $E$. coli $(0 \%)$. This study also indicated that about $54 \%$ of the water samples are incompatible with WHO, (2011) standards (Fig. 3), so the study suggests that these private water selling sites need urgent action to control the source of contamination. The cause of high bacteriological contamination may be due to ineffective disinfectant in the system, contamination during transportation by trucks, water storage tanks in the plants, pipelines, poor hygiene in the plants and post contamination after treatment. Moreover, plastic containers of water may be a source of contamination when reused many times in order to save money.

Most of the drinking water has been collected from private water sites $(54 \%)$ are not fit for drinking. Therefore, we recommend the need to periodically intensify quality control programs with the addition of an appropriate method of disinfection in the system.

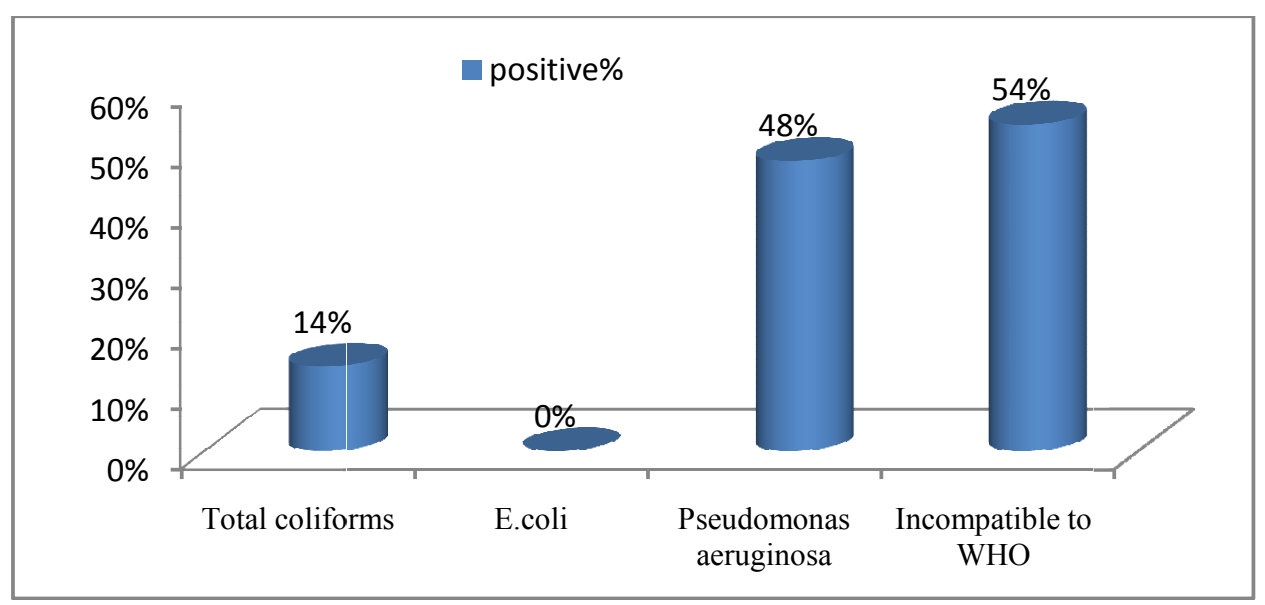

Fig. (3): Contamination percentage of total coliforms, E. coli, and pseudomonas aeruginosa and total incompatible percentage samples to WHO (2011) standards 


\section{CONCLUSIONS}

The present study was concluded that the results of physicochemical parameters ( $\mathrm{pH}$, TDS, and EC) of the drinking water samples collected from the private selling sites of the urban area of Khamis Mushait city were within the permissible limits to WHO (2011) guidelines of drinking water. Bacteriological results indicated that $14 \%$ of the water samples were positive for coliforms contamination, but, Escherichia coli bacterium was not found in all samples. About $48 \%$ of the samples were contaminated with Pseudomonas aeruginosa. Furthermore, our results indicated that 27 samples out of 50 water samples collected from private selling sites (54\%) were incompatible to WHO (2011) standards for drinking water.

\section{REFERENCES}

Ahmed, M. T., S. Greish, S. M. Ismail, Y. Mosleh, N. M. Loutfy and A. El Doussouki (2014). Dietary Intake of Pesticides Based on Vegetable Consumption in Ism Ahmad, M. and A. S. Bajahlan (2009). Quality comparison of tap water vs. bottled water in the industrial city of Yambol (Saudi Arabia). Environ. Monitor. Assess., 159: 1-14.

AlOtaibi, EL Sh. (2009). Bacteriological assessment of urban water sources in Khamis Mashait Governorate, southwestern Saudi Arabia, International Journal of Health Geographic's, 8(16): $1-9$.

APHA (2000). Standard methods for the examination of water and wastewater, $20^{\text {th }}$ ed. American Public Health Association, Washington DC.

APHA (1998). Standard methods for the examination of water and wastewater, $20^{\text {th }}$ ed. American Public Health Association, Washington DC.

IDEXX Laboratories (2013). Quanti-Tray/2000 Insert and Most Probable Number (MPN) Table. Retrieved from. https://www.idexx.com/ resource - library/water/quanti-tray-2000procedure-en.pdf.

IDEXX Laboratories. (2015). Colilert. Retrieved from: https://www.idexx.com/resource-libaray/ water/colilert-procedure-en.pdf.

ISO 16266-2 (2018). Water quality- Detection and enumeration of Pseudomonas aeruginosa - Part 2: Most probable number method.

Liguori G, I. Cavallotti, A. Arnese, C. amiranda D. Anastasi and IF. Angelillo (2010). Microbiological quality of drinking water from dispensers in Italy. BMC Microbial, 10 (1): 19 .

Rifaat, H. (2007). Bacterial Quality of River Nile water at Cairo Region in Egypt Suoseura, 59(1-2): $1-8$.

SAS (1990). User's guide: statistics, version 6. SAS Inst. Inc. Cary, NC. ISBN 0-917382-66-8.

Steel, R. G. D and J. H. Torrie (1980). Principles and procedures of statistics: A Biometrical Approach, $2^{\text {nd }}$ end. New York: McGaw-Hill. ISBN 0-07066581-8.
USEPA. (2004). Water Quality Standards for Coastal and Great Lakes Recreation Waters. 40 CFR Part 131 [OW-2004-0010; FRL-7837-5] RIN 2040-AE63.

Wang, H., M. Edwards J. O. Falkinham and A. Pruden (2012). Molecular survey of the occurrence of Legionella spp., Mycobacterium spp., Pseudomonas aeruginosa, and Amoeba hosts in two chlorinated drinking water distribution systems. Applied and Environmental Microbiology, 78: 6285-6294.

WHO (1996). Guidelines for drinking-water quality Second ed., Geneva. World Health Organization,

WHO (1998). Guidelines for drinking water quality second Ed, Health Criteria and other supporting information, Geneva, World Health Organization, 2: 9400-9491.

WHO (2011). Guidelines for drinking-water quality $4^{\text {th }}$ ed., Geneva. World Health Organization.

Zacheus, O. M., M. J. Lehtola, L. K. Korhonen and P. J. Martikainen (2001). Soft deposits, the key site for microbial growth in drinking water distribution networks. Water Res., 35:17571765 Ismailia, Egypt: A Case Study. Hum Ecol Risk Assess., 20: 779-788. doi: 10.1080/10807039.2013.775893

Anastassiades, M., S. J. Lehotay and F. J. Schenck (2003a). Fast and Easy Multiresidue Method Employing Acetonitrile Extraction/ Partitioning and Dispersive Solid-Phase Extraction for the Determination of Pesticide Residues in Produce. J AOAC Int, 86: 412431.

Anastassiades, M., S. J. Lehotay and F. J. Schenck (2003b). Fast and Easy Multiresidue Method Employing Acetonitrile Extraction/ Partitioning and quot; Dispersive Solid-Phase Extraction \& quot; for the Determination of Pesticide Residues in Produce.

Anastassiades, M., S. J. Lehotay, D. Štajnbaher and F. J. Schenck (2003c). Fast and Easy Multiresidue Method Employing Acetonitrile Extraction/Partitioning and \&quot; Dispersive Solid-Phase Extraction \& quot; for the Determination of Pesticide Residues in Produce. J AOAC Int., 86: 412-431.

AOAC (2007). AOAC Official Method 2007. 01 Pesticide Residues in Foods by Acetonitrile Extraction and Partitioning with Magnesium Sulfate, 1-9. doi: 10.1 .04

Belitz, H-D, W. Grosch and P. Schieberle (2009). Food Chemistry, $4^{\text {th }}$ revise. Springer Berlin Heidelberg.

Bolanos, P. P., J. L. F. Moreno, D. D. Shtereva, A. G. Frenich and J. L. M. Vidal (2007). Development and validation of a multiresidue method for the analysis of 151 pesticide residues in strawberry by gas chromatography coupled to a triple quadrupole mass analyzer. Rapid Commun Mass Spectrom, 21: 22822294. doi: $10.1002 / \mathrm{rcm}$ 
Bowma, B. T. and W. W. Sans (1980). Stability of parathion and DDT in dilute iron solution. Environ Sci Heal B, 233: 233-246.

Chen, M., J. Huang and H. Chien (2007). Residue analysis of fungicide boscalid in cucumbers following applications of boscalid 50\% water dispersible granule. Food Drug Anal, 151: 174-177.

Ermer, J. (2005). Method Validation in Pharmaceutical Analysis Edited by Related Titles from WileyVCH: LC/MS Applications in Drug Development Reference Materials for Chemical Analysis, 83.

FAO (2018). Strawbery Production Statistics. http://www.fao.org/faostat/en/\#data/QC.

Fernandes, V. C., S. J. Lehotay, L. Geis-asteggiante, H. Kwon, H. G. J. Mol, H. van der Kampf, N. Mateusb, V. F. Dominguesa and C. DelerueMatos (2014). Analysis of pesticide residues in strawberries and soils by GC-MS/MS, LCMS/MS and two- dimensional GC-time-offlight MS comparing organic and integrated pest management farming. Food Addit Contam, 31: 262-270. doi: 10.1080/19440049.2013.865842

Frenich, A. G., J. M. Vidal, E. Pastor-Montoro and R. Romero-González (2008). High-throughput determination of pesticide residues in food commodities by use of ultra-performance liquid chromatography-tandem mass spectrometry. Anal Bioanal Chem., 390: 947959. doi: 10.1007/s00216-007-1746-5.

Hiemstra, M. and A. De-Kok (2007). Comprehensive multi-residue method for the target analysis of pesticides in crops using liquid chromatography-tandem mass spectrometry. Chromatogr A, 1154: 3-25.

Jardim, A. N. O. and E. D. Caldas (2012). Brazilian monitoring programs for pesticide residues in food - Results from 2001 to 2010. Food Control 25: 607-616. doi: 10.1016/j.foodcont.2011.11.001

Laymann, W. J., W. F. Reehl and D. H. Rosenblatt (1990). Handbook of Chemical Property Estimation Methods. Amer. Chem. Soc. USA. Washington D. C

Lehotay, S. J. (2011). QuEChERS Sample Preparation Approach for Mass Spectrometric Analysis of Pesticide Residues in Foods. In: Zweigenbaum J (ed) Mass Spectrometry in Food Safety: Methods and Protocols, Methods in Molecular Biology. Springer Science+Business Media, LLC 2011, pp 6591.

Looser, N., D. Kostelac, E. Scherbaum, M. Anastassiades and H. Zipper (2006). Pesticide residues in strawberries sampled from the market of the federal state of BadenWürttemberg in the period between 2002 and 2005. J fur Verbraucherschutz und Leb., 1:
135-141. doi: 10.1007/s00003-006-0022-5.

Lorenz, J. G., L. L. F. Costa, E. A. Suchara and E. S. Sant'Anna (2014). Multivariate Optimization of the QuEChERS-GC-ECD Method and Pesticide Investigation Residues in Apples, Strawberries, and Tomatoes Produced in Brazilian South. J Braz Chem Soc., 25: 15831591. doi: 10.5935/0103-5053.20140143.

Malhat, F. M., N. M. Loutfy and W. Thabet (2014). Dissipation Profile and Human Risk Assessment of Pyrimethanil Residues in Cucumbers and Strawberries. J Heal Pollut., 4: 36-41. doi: 10.5696/2156-9614-4-7.36

Matsumura, M. M., S. P. Margulius and A. M. Saligman (1972). Environmental Toxicology of pesticides.

Saber, A. N., F. M. Malhat, H. M. A. Badawy and D. A. Barakat (2016). Dissipation dynamic, residue distribution and processing factor of hexythiazox in strawberry fruits under open field condition. Food Chem., 196: 1108-1116. doi: 10.1016/j.foodchem.2015.10.052

Safi, J. M., N. S. Abou-Foul, Y. Z. El-Nahhal, A. H. El-Sebae (2002). Monitoring of pesticide residues on cucumber, tomatoes and strawberries in Gaza Governorates, Palestine. Nahrung/Food, 46: 34-39.

Schreiber, A., O. Cabrices and W. E. Brewer (2013). Automated Sample Preparation and Analysis Workflows for Pesticide Residue Screening in Food Samples using DPX-QuEChERS with LC-MSMS.

Sójka, M., A. Miszczak, P. Sikorski, K. Zagibajlło, E. Karlińska and M. Kosmala (2015). Pesticide residue levels in strawberry processing byproducts that are rich in ellagitannins and an assessment of their dietary risk to consumers. NFS J 1 : 31-37. doi: 10.1016/j.nfs.2015.09.001

Ueno, E., H. O. I. Saito and H. Matsumoto (2003). Determination of Nitrogen- and PhosphorusContaining Pesticide Residues in Vegetables by Gas Chromatography with NitrogenPhosphorus and Flame Photometric Detection after Gel Permeation Chromatography and a Two-Step Minicolumn Cleanup. J AOAC Int., 86: 1241-1251.

Wilkowska, A. and M. Biziuk (2011). Determination of pesticide residues in food matrices using the QuEChERS methodology. Food Chem., 125: 803-812. doi: 10.1016/j.foodchem.2010.09.094

World Health Organization (2014). Harmonization Project Document 11 Guidance document on evaluating and expressing uncertainty in hazard characterization. World Heal Organ, $\mathrm{xx}+171$. doi: ISBN 9789241507615

Zalom, F. G., D. V. Shaw and K. D. Larson (2006). Strawberry Insects and Mites in California: Ecology and Control. Encycl. Pest Manag., 13. 


\section{التقيم البكتيريولوجي والفيزيوكيميائي لمياه الشرب المجمعة من مواقع البيع الخاصة في

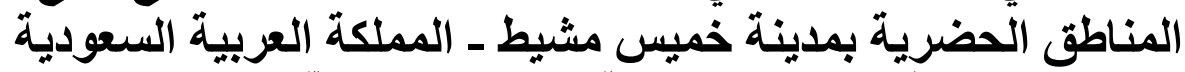

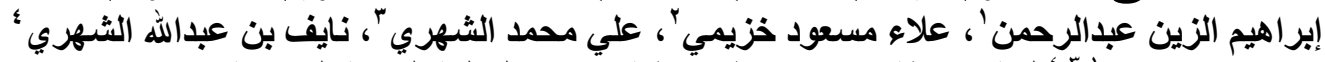

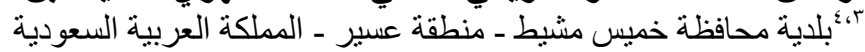

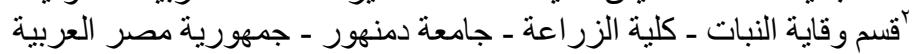

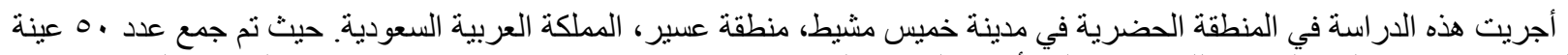

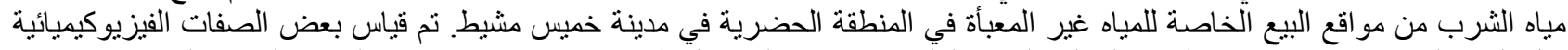
مثل الرقم الهيدروجيني (pH) ، المو اد الصلبة الذائبة الكلية (TDS) و التوصيل الكهربائي (EC) باستخدام الطرق القياه القياسية لتقدير جودة مياه

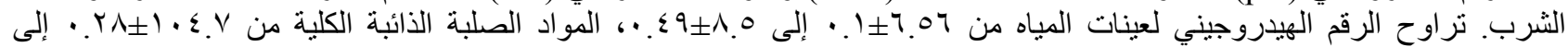

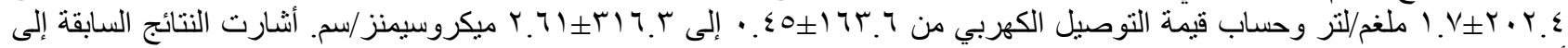

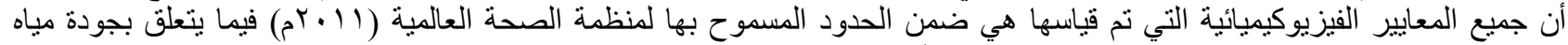

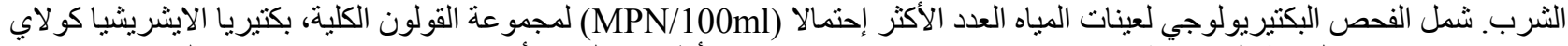

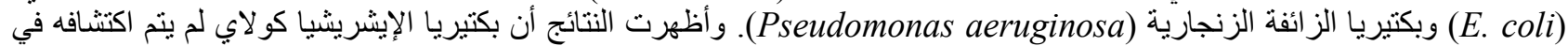

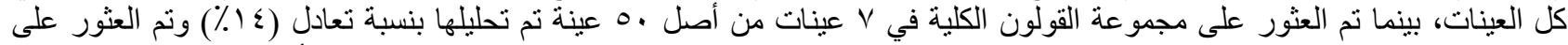

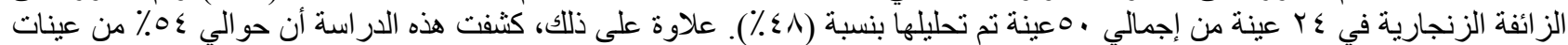
مياه الشرب التي تم جمعها من مواقع البيع الخاصة لا لتو افق مع مع معايير منظمة الصحة العالمية بجودة مياه الشرب. 